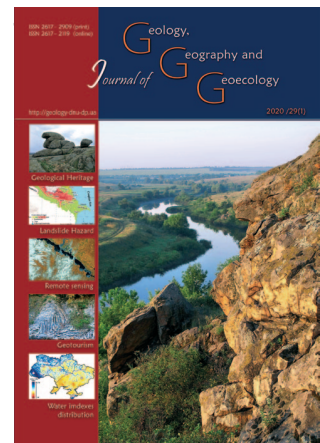

Journal of Geology.

Geography and

Geoecology

Oleh V. Yaholnyk

Journal home page: geology-dnu-dp.ua

Journ.Geol.Geograph. Geology, 29(1), 217-227.

doi: $10.15421 / 112020$

\title{
International legislation as an important instrument in the creation of geoparks in Ukraine
}

Oleh V. Yaholnyk

Oles Honchar Dnipro National University, Dnipro, Ukraine, azuredn@gmail.com

Received: 06.10.2019

Received in revised form: 02.12.2019

Accepted: 08.02.2020

It was determined that the establishment of geoparks in Ukraine is hindered by numerous
problems, particularly: absence of target-legislation, unproductive dialogue with authorities, from local to national and difficult economic conditions. We found that solving the problems should start from the assessment of state and international normative-regulatory acts and characterization of the impact of the latter in the legal field of Ukraine. We found that domestic scientific works do not have many references to the international legislation. Therefore, the necessity arises of developing an international "legal map" in the issue of protection of geoheritage. For this purpose, we analyzed 14,335 international documents relevant for the territory of Ukraine with their respect to their relationship to the protection of nature, natural and cultural heritage, out of which 79 were analyzed in detail. We determined the peculiarities, according to which the international legal acts can be identified and can characterize them by 3 groups: Treaties between states on collaboration; Treaties between states on particular natural objects; important international documents. We determined that 48 of them have different levels of importance in the issue of establishment of Geoparks. We determined that many international documents recommend, encourage, obligate the authorities to support protection of nature, the natural heritage, including geoheritage. With active use of such documents, it is possible to significantly advance in solving the abovementioned problems of establishing Geoparks. Most characterized normative-regulatory acts which are directly or indirectly related to natural objects and territories that could be included in future Geoparks, making them an important tool in preservation of geoheritage. The presented results correspond to all the recent changes in the legislation as at the beginning of 2019 . The results can be used by scientists in the process of establishment of real Geoparks in Ukraine, as well for preservation of geological heritage in general.

Keywords: geopark, geoheritage, international legislation, international document, legal map

\section{Міжнародне законодавство, як важливий інструмент створення геопарків в Україні}

\author{
Олег В. Ягольник
}

Дніпровський національний університет імені Олеся Гончара, Дніпро, Україна, azuredn@gmail.com

Анотація. У статті розглядається міжнародне законодавство, як інструмент у процесі створення геопарків в Україні. Оскільки поняття «геопарк» відносно нове для Свропи, а тим більш для України, є необхідність вивчення юридичних аспектів цього питання. Встановлено, що створення геопарків в Україні має безліч проблем, зокрема: відсутність цільового законодавства, недієвий діалог із владою від місцевих до національних рівнів та складні економічні умови. 3’ясовано, що починати вирішення цих проблем потрібно з оцінки державних й міжнародних нормативно-правових актів та характеристики впливу останніх в правовому полі України. Виявлено, що у вітчизняних наукових роботах дуже мало посилань на міжнародне законодавство. Тому виникає необхідність створення міжнародної «юридичної мапи» у питанні охорони геоспадщини. Із цією метою було проаналізовано 14335 міжнародних документів, які діють на території України, щодо їх відношення до охорони природи, природної та культурної спадщини, з яких детально опрацьовано 79. Визначено особливості, згідно яким міжнародні правові акти можна віднести та охарактеризувати за 3 групами: Угоди між державами про співробітництво; Угоди між державами про конкретні природні об'єкти; Важливі міжнародні документи. Встановлено, що 48 з них має різного рівня цінність у питанні створення геопарку. 3'ясовано, що багато міжнародних документів рекомендує, спонукає, зобов'язує владу позитивно діяти у напрямку охорони природи, природної спадщини, у тому числі й геоспадщини. При активному використанні таких документів можливо суттєво просунутись у вирішені зазначених проблем створення геопарку. Більшість охарактеризованих нормативноправових актів напряму або опосередковано стосуються природних об'єктів та територій, які можуть входити до майбутніх геопарків, що робить їх важливим інструментом у питанні збереження геоспадщини. Викладені результати відповідають усім останнім змінам у законодавстві на початок 2019 року. Результати можуть бути використані науковцями для створення реального геопарку в Україні, так і в цілому у питанні збереження геологічної спадщини. 
Introduction. At a time when the world community, and especially Europe, is moving towards conservation of the geoheritage by establishing Geoparks in the global network, geosites and objects protected by international institutions - there are no such objects in Ukraine. Scientists of many countries are already studying how to improve the work and the infrastructure of the existing Geoparks, as for example in Brazil and Germany (Corrado Venturini, 2019; Eduardo Guimaraes, Paulo Felipe, Ribeiro Bandeira, Joao Marcos Ferreira de Lima Silva, Rafael Celestino Soares, 2018), in Holland the geopark is considered a brand and the attitude of the inhabitants to it is being studied (Arie Stoffelen, Peter Groote, Erik Meijles, Gerd Weitkamp, 2019), therefore: the relevance of solving the problem of establishing such Geoparks in Ukraine is of great importance. In the previous studies, one of the determined problems was the absence of "a legal map" (Yaholnyk, Manyuk, 2015) in the issue of establishing a geopark, and the corresponding Ukrainian laws were analyzed. However, a no less important aspect of creating a "legal map" is the international legislation.

In most Ukrainian studies on establishing Geoparks, a certain pattern emerges. Practically in all the works, there is either only a small number of references to the international legislation, or a complete absence of such references (Tofig Rashidov, Talat Kangarli, Ilkin Kangarli, 2018; Kravchuk, Bohutskyi, Zinko, Brusak, Krychevska, Blahodyr, Shevchuk, 2013; Manyuk, 2007; Maria Helena Henriques, José Brilha, 2017; Shevchuk, 2011). Some researchers explain such pattern by the fact that legal aspects are complex and do not stimulate those who are trying to legitimize geological monuments (Heichenko, Flore, 2014). Among the publications of foreign authors, the norms of international law are mentioned and explored, but not entirely, as for example in Azerbaijan, where the aspect of creating Geoparks also remains unsolved, the importance of the international law is almost ignored; (Tofig Rashidov, Talat Kangarli, Ilkin Kangarli, 2018) in the articles focused on the study of the legislation, 5 to 10 different international acts are mentioned, for example in the article "Geoconservation legal status and geopark establishment in Greece" (Haidarlis, Sifakis, Brachou, 2017). Therefore, the relevance of the results of the studies provided in the article have an exceptional character for Ukraine - because the mentioned documents were signed or ratified particularly by Ukraine, and furthermore the methodology of the studies, conclusions, list of international acts and their significance for preservation of geoheritage can be useful for foreign researchers as well.
The objective of the study was to develop an international "legal map" regarding creation of a geopark within the legal field of Ukraine, based on the existing normative acts which our country has ratified and signed.

It was found that in the international legislation which is in force in the Ukrainian legal field, no term "geopark" exists. Therefore, since target documents are absent, normative acts approximated to the problem should be used.

Firstly, we should determine what the international law is composed of and how it functions. The international legal act as the main legal source of the current international law can have different names and forms: agreement, declaration, contract, communiqué, pact, convention, charter, tract, protocol, statute, exchange of diplomatic correspondence, etc. Differences in the names do not have a legal significance, because a treaty regardless of its name is an agreement which creates rights and obligations for the parties, therefore all of them have legal force (Skakun, 2001)

Concluding of international treaties is regulated by The Vienna Convention on the Law of Treaties between countries and international organizations, adopted in 1986 at the Conference under the aegis of the UN in Vienna. Among the stages of concluding an international treaty, a special place belongs to its ratification (The Law of Ukraine, 1986). Ratification (approval) is an act of international right using which a state, through the responsible bodies with the rights to conclude agreements, expresses its agreement to take responsibility within the international framework according to a corresponding treaty (Skakun, 2001).

We analyzed the international documents, the legal force of which extends to Ukraine, and attention was paid to their relation to the aspect of protection of nature, natural and cultural heritage, particularly everything that can directly or indirectly be related to the problem of establishing a geopark. Among all legal acts, 79 documents were found and analyzed in detail. Among them, 48 were found to be significant for solving the problem of creating a geopark. They can be conditionally divided into 3 categories:

-Treaties between countries on collaboration (22);

-Treaties between countries on particular natural objects (6);

- Important international documents (20).

Treaties between countries on collaboration. The first category includes international bilateral international treaties about collaboration in the sphere of preserving the environment, between the Ministry of Ecology and Natural Resources of Ukraine, Minis- 
try of the Protection of the Natural Environment of Ukraine, or government of the country with a similar body of power in another country. According to the Vienna Convention on Succession of States in respect of Treaties, Ukraine is successor of all the international normative acts concluded and ratified by the Ukrainian RSR, therefore the agreements signed before the independence have legal force (The Law of Ukraine, 1978). A number of countries the agreements are signed with already have Geoparks, and some, like Uzbekistan, are at the final stage of receiving the status, and therefore they can be asked for help and exchanging experience at the legal level (Table 1).

Table 1. Treaties between states on cooperation directions are formulated. In such documents, issues of monitoring and assessment of actions of collaboration are set out separately. Also, these treaties can initiate creation of various commissions and committees. Then the concluding provisions are written.

An important aspect in the context of establishing a geopark is that most of these treaties in the spheres and directions of collaboration envisage preservation and protection of natural objects, including objects of future Geoparks. For example, the text of the Treaty between the Republic of Latvia and Ukraine mentions: "protection of nature, bio-, -geo- and landscape diversity of the protected territories"; (The Law of

\begin{tabular}{|c|c|c|c|}
\hline $\begin{array}{c}\text { Geographic position in relation to } \\
\text { Ukraine }\end{array}$ & Other Party of the Treaty & $\begin{array}{l}\text { Year of sign- } \\
\quad \text { ing }\end{array}$ & $\begin{array}{l}\text { Number of } \\
\text { Geoparks }\end{array}$ \\
\hline \multirow{6}{*}{ Borders with the territory of Ukraine } & Russian Federation & 1994 & - \\
\hline & Belarus & 1994 & - \\
\hline & Slovakia & 1994 & 1 \\
\hline & Poland & 1993,1992 & 1 \\
\hline & Romania & 1991 & 1 \\
\hline & Hungary & 1990 & 2 \\
\hline \multirow{13}{*}{ located on one continent } & Latvia & 2017 & - \\
\hline & Lithuania & 2016 & - \\
\hline & France & 2015 & 7 \\
\hline & Macedonia & 2010 & - \\
\hline & Sweden & 2008 & - \\
\hline & Turkey & 2007 & 1 \\
\hline & Bulgaria & 2003 & 1 \\
\hline & Uzbekistan & 1998 & $1 /-$ \\
\hline & Denmark & 1994 & 1 \\
\hline & Israel & 1994 & - \\
\hline & Germany & 1993 & 6 \\
\hline & Georgia & 1993 & - \\
\hline & Italy & 1989 & 10 \\
\hline \multirow{2}{*}{ located on another Continent } & USA & 1992 & - \\
\hline & Canada & 1989 & 3 \\
\hline
\end{tabular}

All treaties are small in size - containing 4 to 14 articles, in which the parties first approve their intentions about cooperation. Further, the main spheres and directions of cooperation are enlisted, usually containing such issues as: ecology, protection of the environment, monitoring, development, coordinated survey and mutual help, pollution and wastes, and many others. Variability of the issues increases if the countries are located close to one another, for example in the treaty with Belarus, 26 such directions can be seen. Then the forms of collaboration in different
Ukraine, 2010), with Republic of Bulgaria: "Protection and rational use of the territories and objects of nature protection fund" (The Law of Ukraine, 2003) - there are many such examples. All of them can contribute to cooperation and help of other countries in establishing Geoparks. Also exchange of experience and data would be useful.

Treaties between countries on particular natural objects. Treaties between countries on collaboration sometimes contain directions related to particular natural objects, but more significant are target documents 
on such objects. In Ukraine, there are 3 such objects. According to the surveys conducted earlier, the most promising territories for Geoparks in Ukraine are national parks (Yaholnyk, Manyuk, 2015). Many of the objects protected by international treaties are located in the territory of operating national parks in Ukraine and many of them are promising regarding establishment of a geopark. Therefore, the abovementioned objects and normative acts related to them are of great significance.

Mountain system of the Carpathians. The main protected object in our country is the mountain system of the Carpathians. At least 4 documents are related to it. At the same time, in the Carpathians, a lot of national parks and separate zones with geological objects are located - therefore these territories are considered very promising. They include territories of the national parks Zacharovany Krai, Uzhansky, Skolivsky Beskydy, Verhovynsky, Halytsky, Hutsulshchuna, Karpatsky, Syniohora (Kravchuk, Bohutskyi, Brusak, Zinko, Shevchuk, 2012; Kravchuk, Bohutskyi A, Zinko, Brusak, Krychevska, Blahodyr, Shevchuk, 2013; Zinko, 2011). One of the first international documents on the Carpathians was the Krakow Declaration "Implementation of the Pan-European Ecological Network (PEEN) establishment of the "Green Backbone of Central and Eastern Europe" (The Law of Ukraine, 1998). Mostly, the document concerns the protection of the ecosystem of the Carpathians and the river basin of the Danube, the main theses are: sustainable development of the highland area and the pre-mountain area, nature-protection education, support and development of tourism, solving the problems of the local population - all of them completely correspond to the purpose of establishment of a geopark according to the criteria of UNESCO (The Law of Ukraine, 1998; UNESCO, 2015).

In 2003 the main document on protection of the Carpathians was signed - the "Framework Convention on the Protection and Sustainable Development of the Carpathians", signed by 8 countries: Ukraine, Poland, Romania, Serbia, Montenegro, Hungary, Slovakia, Czech Republic. The main theses worth noting are: Article 4 Part 1 - policy orientated towards preservation, sustainable use and restoration of the landscape diversity; providing a high level of protection and sustainable use of natural resources and semi-natural environments (The Law of Ukraine, 2004) Article 9 Part 1 - foster sustainable tourism, based on the unique nature and landscapes, benefiting the local population; (The Law of Ukraine, 2004) Article 13 Part 1 - increase in ecological knowledge and support of the corresponding education institu- tions and programmers; (The Law of Ukraine, 2004) - that is protection, tourism, increase of the awareness and communication with the public, which are some of the main criteria of UNESCO regarding establishment of geopark (UNESCO, 2015).

To the Framework Convention, according to Articles 18 and 19, changes, protocols and appendices could be added. Among such protocols important are "2009 Protocol on Preservation and Sustainable Use of Biological and Landscape Diversity in the Framework Convention on the Protection and Sustainable Development of the Carpathians" - the most important addition, because in more detail it reveals the problem of protection of nature objects, $32^{\text {nd }}$ Article of this document focuses on the protection of landscape and its diversity; (The Law of Ukraine, 2004) "2009 Protocol on the Sustainable Tourism within the Framework Convention on the Protection and Sustainable Development of the Carpathians" is also an important addition, because it fully corresponds to the purpose of establishment of a geopark (The Law of Ukraine, 2004).

The basin of the Dniester river. In 2017, the Treaty between the Government of the Republic of Moldova and the Cabinet of Ministers of Ukraine on Cooperation in the Field of Protection and Sustainable Development of the Dniester River Basin was signed. The ecosystems of the basin of the river belong to the national parks such as the Dniester Canyon and Lower Dniester National Nature Park, which in turn are candidates for future Geoparks (Zinko 2012, Kravchuk, Bohutskyi, Zinko, Brusak, Krychevska, Blahodyr, Shevchuk, 2013) According to the Article 1 Part 1 - one of the goals of the treaty was collaboration in ecological use and protection of the natural resources and ecosystems of the Dniester river - among which, there are many geological objects which could be the basis for establishing a future geopark, including for example, canyon-like sections of the Dniester river (The Law of Ukraine, 2017). The treaty could be a valuable tool, if a geopark would be established in the territories being protected by this normative act (The Law of Ukraine, 2017).

The coast of the Black and the Azov seas. The Convention on the Protection of the Black Sea against Pollution was signed in 1992 and ratified in 1994. Later, in 2007 the Black Sea Biodiversity and Landscape Conservation Protocol were ratified. The Protocol and the Convention protecting the Black Sea are substantial documents which contain many measures, aims, recommendations, duties regarding the ecology of the Black Sea in general (The Law of Ukraine, 2007). However, in the context of establishing a geopark, in- 
teresting are the sections on the protection of the landscape, landscape diversity and coastal zones. These documents, apart the sea itself, protect the coastal territories, including geological objects on the territories which are promising for establishment of a geopark, in the Crimean area: the Bulganak field of mud volcanoes, Opuksky Nature Reserve, Kara Dag, Grand Canyon of Crimea (Kravchuk , Bohutskyi, Zinko, Brusak, Krychevska, Blahodyr, Shevchuk, 2013).

Important international documents. "Important" means significant in the context of the problem of establishing Geoparks. Knowledge of international law is a big step towards the idea of establishing protected geological territories. Every international document always refers to the earlier signed documents in force. In the European Community any document: application, request, agreement, etc has greater value if it refers to other legal acts, because then it functions in the legal field of such documents. Contact with the Ukrainian local authorities of regional and state levels mostly concerns request for help for drawing up documents - from business documents, applications, addresses to the projects of laws and amendments in them. And the more references there are to the Ukrainian or international legislations, the more substantial they will be in the legal context.

Because the terms "geopark" and "geological monument" are mentioned in none of the documents, the attention should be paid to the terms close to such, or which partly characterize them, for example: environment, natural environment, natural resources, landscapes, ecosystem and others.

Therefore, we propose considering all the international documents in which the protection of natural objects is mentioned, which would directly or indirectly help in the process of establishment of geopark - their name, content and usefulness. A total of 28 such documents were selected; they will be considered in the order of appearance.

The first document is the Statute of the International Union for Conservation of Nature and Natural Resources signed in 1948 (The Law of Ukraine, 1948). The International Union for Conservation of Nature (IUCN) and Nature Resources becomes a good ally in the questions of the protection of the environment. Its goals fully correspond to the purpose of establishing Geoparks. Particular theses of the Statute deserve special attention. According to Article I Part 1, the Union supports the collaboration between separate persons who work on preservation of natural resources and nature protection - that is help in establishing Geoparks could be asked for by both group of scientists or even one scientist (The Law of
Ukraine, 1948). Part 2 refers to encouragement of any international and national measures for preservation of organic life and natural environment - areas, natural objects which are subjects of scientific, historical and aesthetic interest. Such areas and objects also include geological relics (The Law of Ukraine, 1948). The IUCN has developed a system of categories of protected nature territories, in which the highest level, «Ia» is a nature reserve of strict regime which may be located in particular on notable or highly-representative examples of geological systems. An important direction of the work is also implementation of the educational programmers and propaganda aimed at persuading the public of the necessity of preserving natural resources and protection of nature (The Law of Ukraine, 1948).

In 1954 the Statute of the United Nations Educational, Scientific and Cultural Organization was adopted. This document is the establishment of UNESCO. One of the main goals of the organization, according to the first article, is the preservation and protection of the global heritage of the mankind, including geological heritage. This principle became the basis for the future preservation of the geoheritage and establishment of network of Geoparks (The Law of Ukraine, 1954).

In 1957 the Treaty establishing the European Community was signed - one of the most important documents of the previous century within Europe. Apart from the main provisions of functioning and integral principles of the European Community, notable is section XIX titled "Environment" composed of three articles - 174,175,176 (The Law of Ukraine, 2005). The articles describe preservation, protection, solving problems related to the environment, use of natural resources. The geologic objects of a territory which are promising for establishing a geopark are understood as coming under these terms, therefore they also become objects for which this normative act functions. Also, the section describes collaboration of the member states with third countries, which Ukraine is now (The Law of Ukraine, 2005). Thus, this document is a practical tool in questions of help from the EU countries, exchanging experience on establishing Geoparks, etc.

In 1971 the Convention on Wetlands of International Importance especially as Waterfowl Habitat was adopted - also known as the Ramsar Convention, finally ratified by Ukraine in 1996. Wetlands are present in most of the territories promising for establishment of Geoparks, most (over 10) of which are included in the Ramsar International list. Protection of these objects in the context of establishing Geoparks 
is of great significance. According to Article 1 wetlands are the territories of swamps, marshes, bogs, mires, water bodies of constant or temporary, lentic or circulating, fresh-water or saline ones (The Law of Ukraine, 1996). Important is the statement in Article 4 Part 1 on supporting the preservation of such territories by creating nature reserves, regardless of whether they are included to the international list or not, and provision of care for them (The Law of Ukraine, 1996). That is if in the territory, such areas would be present, this convention would also protect the territory of the geopark.

In 1972 the Recommendation concerning the Protection, at National Level, of the Cultural and Natural Heritage was adopted. This is a very important international document, containing direct recommendations on protection of natural heritage at the national level, i.e. inside the country. It describes in detail what the natural heritage is: "natural features consisting of physical and biological formations or groups of such formations, which are of special value from the aesthetic or scientific clause of view; geological and physiographical formations and precisely delineated areas...", “...natural sites or precisely delineated natural areas of special value for science, conservation or in terms of natural beauty, or in their relation to the combined works of man and of nature" (The Law of Ukraine, 1972).

The ultimate goal of this document is protection, preservation and popularization of cultural and natural heritage - this should be supported by the state, becoming a determining factor of national development (The Law of Ukraine, 1972). State organs should increasingly find ways to finance the preservation and popularization of the heritage, with possible involvement of private interests. Also an entire section focuses on financial measures for the support at all the levels: local, regional and national, benefits for private interests, etc (The Law of Ukraine, 1972).

One of the most important sections is "Educational and cultural action" because its content completely coincides with the recommendations of UNESCO on establishment of Geoparks in the aspect of education (UNESCO, 2015). In general, the document is important in terms of contact with the authorities at the national level and is one of the additional tools which can be referred to (The Law of Ukraine, 1972).

In 1972 the Declaration of the UN Conference on the Human Environment was signed. It is worth noting some important theses: Part 1 of the Declaration, clause 6 - improvement and protection of the human environment for the present and future generations is the most important goal of the mankind;
(The Law of Ukraine, 1972) clause 7 - appeal to all governments and nations to put maximum efforts for the protection and improvement of the environment; (The Law of Ukraine, 1972) Part 2, Principle 2 - natural resources of the Earth and the most representative examples of the natural ecosystems should be preserved; (The Law of Ukraine, 1972) - these clauses are important, they can be referred to practically in any nature-protection document.

Principle 24 states that the international problems related to the protection and improvement of the environment should be solved by cooperation of countries, based on multi-party and bilateral treaties. According to Principle 25, the State should support the activity of international organizations for their coherent, efficient and dynamic role in the work on the protection and improvement of the human environment - the latter principle emphasizes the problem in Ukraine, for the state does not contribute to cooperation with the UNESCO in the issue of establishing Geoparks, therefore this principle should be used in the dialogue with the authorities (The Law of Ukraine, 1972).

In 1972 the most important of all international documents regarding the establishment of Geoparks was adopted - the Convention on the Protection of the Global Cultural and Natural Heritage (The Law of Ukraine, 1988). According to Article 2 of the Convention, the "natural heritage' in particular is understood as "geological and physiographical formations and precisely delineated areas ... of outstanding universal value from the point of view of science or conservation; natural sites or precisely delineated natural areas of outstanding universal value from the point of view of science, conservation or natural beauty" - this is the main notion which should be used in determining the natural heritage (The Law of Ukraine, 1988).

According to Article 3, our country should determine and distinguish different values on its territory, according to the definitions of cultural and natural heritage (The Law of Ukraine, 1988). According to Article 4 the countries are obliged to provide determination, protection, preservation and popularization of the natural heritage. (The Law of Ukraine 1988). Article 5 mentions how particularly it should be done, i.e.: pursue general policy orientated towards provision of the cultural and natural heritage with certain functions in the public life; take corresponding legal, administrative and financial measures; encourage scientific studies in this sphere - these articles can be referred to in the process of establishing Geoparks (The Law of Ukraine, 1988). Article 6, part 1 contains an important thesis that the cultural and natural relics are the global heritage, for the protection of which the 
international community should cooperate (The Law of Ukraine, 1988). To implement all of that, the Intergovernmental Committee for the Protection of the Cultural and Natural Heritage of Outstanding Universal Value, called the World Heritage Committee was established. Its work is regulated by the III section of the Convention. The Committee composes, enlarges and publishes the "World Heritage List", enlisting outstanding cultural and natural relics from the lists provided by the countries which are the parties in the Convention. One can be familiarized with this process in Article 11 (The Law of Ukraine, 1988). The subjects of the application can be: protection, preservation, promotion or restoration of these relics, partly funded by international organizations. For these purposes the Fund for the Protection of the World Cultural and Natural Heritage was established, as indicated in Section IV of the document. Besides financial, the Committee can provide other forms of help, as described in Article 22 (The Law of Ukraine, 1988).

An important section is also VI section "Educational Programmers", which indicates what the party countries should aim for, using the corresponding means, and particularly educational and informational programmers, increasing the respect and commitment of their nations to cultural and natural heritage; obligation to broadly inform the public about the measures taken for the execution of the Convention. It is hard to overestimate the importance of this document on the protection of nature and the geological heritage in particular (The Law of Ukraine, 1988).
In 1978 the Statute of the International International Council on Monuments and Sites was adopted. In our country, there is a Ukrainian unit of this organization, ICOMOS. It deals with the issues of protection of cultural monuments and historical places (The Law of Ukraine, 1978).

At first glance, it seems that the organization has an indirect relation to Geoparks, but if we consider the statute and the main law of this International Board, this assumption is refuted. Very useful is Article 3, Part 1, Clause b on objects which together with the landscape, historic, scientific and ethnological value, and the main thing, its natural environment, form "ensembles" which are protected by this organization (The Law of Ukraine, 1978). There are such "ensembles" in our possible Geoparks, for example there is monastery in the National Park Sviati Hory, which is built into Cretaceous rocks. Because this is an international organization and one of the structural units of UNESCO, determination of one of the objects of geopark as an object protected by the ICOMOS would foster the process of establishment of Geoparks.

There is a number of normative acts which specialize particularly on wildlife, but contain aspects useful for establishment of geopark and protection of geological objects (Table 2).

In 1991 the Protocol on Cooperation between the Ukrainian Soviet Socialist Republic and UNESCO was adopted. It has legal force according to the Vienna Convention on Succession of States in respect of Treaties, therefore all the theses regarding Ukrai-

Table 2. Normative acts specializing in wildlife

\begin{tabular}{|c|c|c|c|}
\hline Title & $\begin{array}{l}\text { Ratifi- } \\
\text { cation } \\
\text { year }\end{array}$ & Nomenclature & Important theses \\
\hline $\begin{array}{l}\text { Convention on the } \\
\text { Conservation of European } \\
\text { Wildlife and Natural } \\
\text { Habitats }\end{array}$ & 1979 & $\begin{array}{l}\text { Section II "Protection of the } \\
\text { environments" (The Law of } \\
\text { Ukraine 1996) }\end{array}$ & $\begin{array}{l}\text { Protection of territories with representatives of flora and } \\
\text { fauna }\end{array}$ \\
\hline World Charter for Nature & 1982 & $\begin{array}{l}\text { "General principles", } \\
\text { "Functions" (The Law of } \\
\text { Ukraine 1982) }\end{array}$ & $\begin{array}{l}\text { Document, among others goals, is orientated at protection } \\
\text { of unique areas, all types of ecosystems and habitats of rare } \\
\text { species }\end{array}$ \\
\hline $\begin{array}{l}\text { Declaration on Conserva- } \\
\text { tion of Flora, Fauna and } \\
\text { Their Habitats }\end{array}$ & 1988 & $\begin{array}{c}\text { Clause } 8 \\
\text { (The Law of Ukraine, 1988) }\end{array}$ & $\begin{array}{l}\text { Practically all the goals mention protection of environments } \\
\text { of flora and fauna. Significant aim is strengthening the ex- } \\
\text { isting national parks and other protected natural territories } \\
\text { - which directly corresponds to the transition of the nature } \\
\text { territories protected at the national level to internationally- } \\
\text { protected geopark }\end{array}$ \\
\hline $\begin{array}{l}\text { Convention on Biological } \\
\text { Diversity }\end{array}$ & 1992 & $\begin{array}{l}\text { Article } 2 \text { (The Law of } \\
\text { Ukraine 1992) }\end{array}$ & $\begin{array}{l}\text { This document defines the term which is mentioned in other } \\
\text { normative acts, its definition particularly relates to geologi- } \\
\text { cal objects. Specifically: "means a dynamic complex of } \\
\text { plant, animal and micro-organism communities and their } \\
\text { non-living environment interacting as a functional unit." }\end{array}$ \\
\hline
\end{tabular}


nian SSR are in force for modern Ukraine. Because the country has joined the Convention on Protection of the Cultural and Natural Heritage of 1972, among others, UNESCO would welcome applications from Ukraine for inscription of new natural locations for the World Heritage List (The Law of Ukraine, 1991). UNESCO and Ukraine have agreed that in their collaboration they shall take into consideration this Protocol and implement measures on the following development and enlargement of statements in practice (The Law of Ukraine, 1991). Referring to this document will positively contribute to the dialogue with UNESCO on the subject of establishing Geoparks.

In 1992 the Convention on the Protection and Use of the Transboundary Watercourses and International Lakes was approved. Because the basins of rivers are geological objects, and in some cases, (for example, the River Dniester) prominent objects for establishment of Geoparks (Kravchuk , Bohutskyi, Zinko, Brusak, Krychevska, Blahodyr, Shevchuk, 2013), this document has great value for the protection of such geological territories. The whole document contains articles on the protection of such objects (The Law of Ukraine, 2003).

In 1992 the Rio de Janeiro Declaration on Environment and Development was adopted. The document contains fundamental principles on which most normative acts on the nature protection are based . A separate mention should be made for Principle 10 about development and support of the awareness and participation of the population by broad provision of information by the state (The Law of Ukraine, 1992). This corresponds to one of the criteria of the UNES$\mathrm{CO}$ on establishment of Geoparks (UNESCO, 2015)

In 1995 the Ecological Programme for Europe was adopted. This is systematization of most natureprotection documents which are relevant for the territory of Europe, compiled into one programme. The programme emphasizes growth of the potential of the existing nature-protection organizations, most of which are mentioned in this article. Moreover, there is a whole section aimed at improvement of protection of biological and landscape diversity, which can be referred to in the process of establishment of Geoparks (The Law of Ukraine, 1995).

In 1998 the Convention on Access to Information, Public Participation in Decision-Making and Access to Justice in Environmental Matters was adopted. It is an important document which encourages authorities to enter into dialogue and distribute information among the population of Ukraine. This law contains some statements which could be used during communication with the authorities, particularly Article 3 ,Clause 3 on supporting ecological educa- tion and improvement of the level of public awareness of problems of the environment, corresponding to the criteria of UNESCO for the establishment of Geoparks - ecological education of the public (The Law of Ukraine, 2005; UNESCO, 2015). Also no less important is Clause 4 of Article 3, describing the provision of required recognition of organizations which are working for protection of the environment and provision of needed support, which is very important for organizations involved in preservation of geological relics in dialogue with authorities (The Law of Ukraine, 2005).

In 1999 the Treaty between Ukraine and the United States of America on Regional Ecological Center in Ukraine was signed. (The Law of Ukraine 1999) In 2000 it was adopted at the state level. The Regional Ecological Center (REC) is one of the international organizations which work on protection of the environment. In 2000, Ukraine, at the international level and state levels, approved the creation of a center of REC in the country. Up to 2018 , according to different data, it implemented 40-60 projects, and in 2018 the legal status and opening of its office in Kyiv were ceremonially signed by Deputy Minister of Ecology and Natural Resources Mykola Kuzio and executive director of the REC Myhailo Dymovski (UNIAN, 2018). Apart the support and consultative help, the REC has a programme of grants which could be used during the establishment of Geoparks (REC Kyiv, 2000).

In the Statute of REC in Kyiv, each clause indicates help to all those interested in the protection of the environment, from consultations to financial support, etc. Clause 8 of the Statute indicates the main task which corresponds to the main goals and criteria of the UNESCO in the aspect of Geoparks (The Law of Ukraine 1999; UNESCO, 2015).

In 2000 the European Landscape Convention was adopted. It is an important normative act indicating and characterizing landscape as natural object, according to Article 1, clause a: as territory the character of which is the result of impact or interaction of natural and human factors - which according to legal practice can be used as definitions in other documents which lack definition (The Law of Ukraine, 2005). Because most geological objects in the territory of possible Geoparks have more aesthetic value, they can be considered landscape relics, as for example, the Cretaceous rocks in the Dvorichansky National Park. Landscape objects are protected according to this Convention, allowing them to be used and referring to it in the process of establishment of Geoparks (The Law of Ukraine, 2005).

In 2000 the UN Millennium Declaration was adopted. This is an important document for the whole of 
mankind, consisting of the main theses on development of the global community. According to clause 6, the UN considers that a number of fundamental values shall be exceptionally important for international relations in XXI century shall be a number of fundamental values, including particularly: "Respect to nature" and also section IV focused on protection of the environment - this again confirms the importance and relevance of the idea of establishing Geoparks in Ukraine. This document is important and may be referred to in the dialogue with authorities and international organizations (The Law of Ukraine, 2000).

Conclusions. Processing and analysis of all the above mentioned international acts and assessments in their legal field of Ukraine, allows us to draw the following conclusions:

1. In the legal field of the country, the laws on protection of geoheritage are incomplete, though our state has ratified and signed many international normative acts which positively affect the issues of establishment of Geoparks.

2. An international "Legal map" was developed, which should be used during developing documents at the state level. This would provide these documents with legal force.

3. On the question of establishment of Geoparks, one should apply for help from other countries with which corresponding treaties are signed.

4. In the international legislation, no terms "Geoparks" and "geologic relic" are present, and therefore the protection of geological objects should be considered using more approximate terms: environment, habitat, ecosystem, natural objects, natural heritage, etc.

5. Issues of protection of the geoheritage is a subject of growing concern within the global community and corresponding steps towards its preservation are being made.

6 . We determined that many documents oblige our state to support protection of geoheritage, being an important tool in dialogue with authorities, which should be used.

7. Results of this work should bring our country closer to the establishment of Geoparks in Ukraine.

\section{References}

Arie Stoffelen, Peter Groote, Erik Meijles, Gerd Weitkamp, 2019. "Geoparks and territorial identity: A study of the spatial affinity of inhabitants with UNESCO Geopark De Hondsrug» The Netherlands.doi: 10.1016/j.apgeog.2019.03.004

Corrado, Venturini, 2019. «Anleitung für geopark-führer» Servizio Geologico - Direzione Centrale Ambi- ente ed Energia - Reg. Aut. Friuli Venezia Giulia - Geopark Karnisken.

Eduardo Guimaraes Paulo Felipe Ribeiro Bandeira, Joao Marcos Ferreira de Lima Silva, Rafael Celestino Soares, 2018. «Matrix of Priorities for the Management of Visitation Impacts on the Geosites of Araripe UNESCO Global Geopark» (NE Brazil). doi: 10.3390/geosciences 8060199

Heichenko, M. V., Flore N. V., 2014. Do pytannia vyvchennia i vykorystannia obiektiv heolohichnoi spadshchyny Ukrainy [To an issue of studying and use of objects of geological Ukraine of heritage], Mineral resources of Ukraine №3 7-9 UkrDGRI (In Ukrainian).

Kravchuk, Ia., Bohutskyi, A., Brusak, V., Zinko, Yu., Shevchuk, O., 2012. Proektovani heoparky Ukrainskykh Karpat yak demonstratsiini modeli evoliutsii Zemli [The projected geopark of the Ukrainian Carpathians as demonstration models of evolution of Earth]Scientific bulletin of: Collection of scientific works. - Chernivtsi: Chernivtsi National University, Rel. 612-613: Geography. 102-107. (In Ukrainian).

Kravchuk,Ya., Bohutskyi, A., Zinko,Yu., Brusak,V., Krychevska, D., Blahodyr, S., Shevchuk, O., 2013. Merezha heoparkiv v ukraini: holovni zasady formuvannia [Network of Geoparks in Ukraine: main principles of formation] Bulletin of the Lviv University. Series: Geography. Release 46.203217 (In Ukrainian).

Manyuk, V., 2007. The problem of creation of Network National Geoparks in Ukraine. Dnipropetrovsk, University Bulletin. 9(11),63-67.

Maria Helena Henriques, José Brilha, 2017. «UNESCO Global Geoparks: A strategy towards global understanding and sustainability» doi: 10.18814/ epiiugs/2017/v40i4/017036

M.Haidarlis,A.Sifakis, C.Brachou,2017.«Geoconservation legal status and geopark establishment in Greece». doi: $10.12681 /$ bgsg. 11256

REC Kyiv, 2000. Zagalni-polozhennya [General provisions] Retrieved from http://www.rec-kyiv.org. ua/zagalni-polozhennya/

Shevchuk, O.,2011. Metodychni zasady stvorennia natsionalnykh heoparkiv v Ukraini[Methodological basis of creation of national Geoparks in Ukraine»] Scientific Bulletin of: Collection of scientific works. - Chernivtsi: Chernivtsi National University, 587-588 : Geography. 82-88.(In Ukrainian).

Skakun, O.F., 2001.Teoriia derzhavy i prava [Theory of the state and right]. Khakriv: Konsum. Retrieved from http://politics.ellib.org.ua/pages-1677.html (In Ukrainian).

The Law of Ukraine, 1948. Statut Mizhnarodnoho soiuzu okhorony pryrody ta pryrodnykh resursiv [Statute of the international union of conservation and natural resources]Retrieved from http://zakon. rada.gov.ua/laws/show/998_502/sp:max100 (In Ukrainian). 
The Law of Ukraine, 1954.Statut Orhanizatsii Obiednanykh Natsii z pytan osvity, nauky i kultury [Charter of the United Nations Educational, Scientific and Cultural Organization] Retrieved from http://zakon.rada.gov.ua/laws/show/995_014/sp:max100 (In Ukrainian).

The Law of Ukraine, 1972.Deklaratsiia Konferentsii Orhanizatsii Obiednanykh Natsii z problem otochuiuchoho liudynu seredovyshcha [Declaration of a conference of the United Nations on problems of the human environment] Retrieved from https:// zakon.rada.gov.ua/laws/show/995_454(In Ukrainian).

The Law of Ukraine, 1972. Rekomendatsiia pro okhoronu na natsionalnomu rivni kulturnoi ta pryrodnoi spadshchyny [The recommendation of protection at the national level of cultural and natural heritage] Retrieved from http://zakon.rada.gov.ua/ laws/show/995_724/sp:max100(In Ukrainian).

The Law of Ukraine, 1978. Statut Mizhnarodnoi rady z okhorony pamiatok ta istorychnykh mists (IKOMOS) [Charter of the International Council for Protection of Monuments and Historical Places (IKOMOS) ] Retrieved from http://zakon.rada.gov.ua/laws/ show/995 759/sp:max100 (In Ukrainian).

The Law of Ukraine, 1978. Videnska konventsiia pro pravonastupnytstvo derzhav shchodo dohovoriv [The Vienna Convention on Succession of the States Concerning Contracts] Retrieved from https://zakon.rada.gov.ua/laws/show/995_185/sp:max100 (In Ukrainian).

The Law of Ukraine, 1982. Vsesvitnia Khartiia pryrody [World Charter for Nature] Retrieved from http://zakon.rada.gov.ua/laws/show/995_453/ sp:max100 (In Ukrainian).

The Law of Ukraine, 1986. Videnska konventsiia pro pravo dohovoriv mizh derzhavamy ta mizhnarodnymy orhanizatsiiamy abo mizh mizhnarodnymy orhanizatsiiamy [Vienna Convention on the Right of Contracts between the States and International Organizations]Retrieved from https://zakon.rada. gov.ua/laws/main/995_a04(In Ukrainian).

The Law of Ukraine, 1988. Konventsiia pro okhoronu vsesvitnoi kulturnoi i pryrodnoi spadshchyny [Convention on protection of the world cultural and natural heritage] Retrieved from http://zakon. rada.gov.ua/laws/show/995 089/sp:max100 (In Ukrainian).

The Law of Ukraine, 1988.Deklaratsiia pro zberezhennia flory, fauny ta seredovyshcha yikh meshkannia [Declaration on preservation of flora, fauna and the environment they inhabit] Retrieved from http://zakon.rada.gov.ua/laws/show/994_400/ sp:max100 (In Ukrainian).

The Law of Ukraine, 1991.Protokol pro spivrobitnytstvo mizh Ukrainskoiu Radianskoiu Sotsialistychnoiu Respublikoiu i Orhanizatsiieiu Obiednanykh Natsii v pytanniakh osvity, nauky i kultury (UNES$\mathrm{KO}$ ) [The protocol on cooperation between USSR and the United Nations in issues of education, science and culture (UNESCO)] Retrieved from http://zakon.rada.gov.ua/laws/show/995_644/ sp:max100 (In Ukrainian).

The Law of Ukraine, 1992.Konventsiia pro okhoronu biolohichnoho riznomanittia vid 1992 roku [Convention on protection of biological diversity of 1992] Retrieved from http://zakon.rada.gov.ua/ laws/show/995_030/sp:max100 (In Ukrainian).

The Law of Ukraine, 1992.Deklaratsiia Rio-de-Zhaneiro shchodo navkolyshnoho seredovyshcha ta rozvytku [Rio Declaration on Environment and Development] Retrieved from http://zakon.rada.gov.ua/ laws/show/995_455/sp:max100(In Ukrainian).

The Law of Ukraine, 1995.Ekolohichna prohrama dlia Yevropy [Ecological programme for Europe] Retrieved from http://zakon.rada.gov.ua/laws/ show/995_803/sp:max100 (In Ukrainian).

The Law of Ukraine, 1996.Konventsiia pro okhoronu dykoi flory ta fauny i pryrodnykh seredovyshch isnuvannia $\mathrm{v}$ Yevropi [The convention on protection of wild flora and fauna and the environment in Europe] Retrieved from http://zakon.rada.gov.ua/ laws/show/995_032/sp:max100 (In Ukrainian).

The Law of Ukraine, 1996 .Konventsiia pro vodno-bolotni uhiddia, shcho maiut mizhnarodne znachennia, holovnym chynom yak seredovyshche isnuvannia vodoplavnykh ptakhiv [The convention on the wetlands having international value, mainly as the habitat of waterfowl] Retrieved from http://zakon. rada.gov.ua/laws/show/995 031/sp:max100 (In Ukrainian).

The Law of Ukraine, 1998.Krakivska deklaratsiia "Realizatsiia Panievropeiskoi Ekolohichnoi Merezhi (PIeEM) stvorennia "Zelenoho Karkasu Tsentralnoi ta Skhidnoi Yevropy" [Krakow declaration: "Realization of Pan-European Ecological Network of a Green Framework of Central and Eastern Europe"] Retrieved from http://zakon. rada.gov.ua/laws/show/994_269/sp:max100 (In Ukrainian).

The Law of Ukraine, 1999. Uhoda mizh Ukrainoiu ta Spoluchenymy Shtatamy Ameryky shchodo Rehionalnoho ekolohichnoho tsentru v Ukraini [Agreement between Ukraine and the USA of a regional ecological center in Ukraine] Retrieved from http://zakon.rada.gov.ua/laws/show/840_044 (In Ukrainian).

The Law of Ukraine, 2000.Deklaratsiia tysiacholittia Orhanizatsii Obiednanykh Natsii [United Nations Millennium Declaration] Retrieved from http://zakon.rada.gov.ua/laws/show/995_621/sp:max100 (In Ukrainian).

The Law of Ukraine, 2003. Uhoda mizh Ministerstvom ekolohii ta pryrodnykh resursiv Ukrainy ta Ministerstvom navkolyshnoho seredovyshcha ta vodnykh resursiv Respubliky Bolhariia pro spivrobitnytstvo $\mathrm{v}$ haluzi okhorony navkolyshnoho seredovyshcha ta ratsionalnoho vykorystannia 
pryrodnykh resursiv [Agreement between the Ministry of Ecology and Natural Resources of Ukraine and Ministry of the environment and water resources of the Republic of Bulgaria on cooperation in environmental protection and rational use of natural resources] Retrieved from http://zakon.rada.gov.ua/laws/show/100_043/sp:max 100 (In Ukrainian).

The Law of Ukraine, 2003.Konventsiia z okhorony ta vykorystannia transkordonnykh vodotokiv ta mizhnarodnykh ozer [Convention on protection and use of cross-border water currents and international lakes] Retrieved from http://zakon.rada.gov.ua/ laws/show/994_273/sp:max100 (In Ukrainian).

The Law of Ukraine, 2004.Ramkova konventsiia pro okhoronu ta stal(In Ukrainian).yi rozvytok Karpat [Framework convention on protection and sustainable development of the Carpathians] Retrieved fromhttp://zakon.rada.gov.ua/laws/ show/998_164/sp:max100 (In Ukrainian).

The Law of Ukraine, 2005.Dohovir pro zasnuvannia Yevropeiskoi Spilnoty [Contract of foundation of the European community] Retrieved from http://zakon.rada.gov.ua/laws/show/994_017/sp:max100 (In Ukrainian).

The Law of Ukraine, 2005. Yevropeiska landshaftna konventsiia [European landscape convention] Retrieved from http://zakon.rada.gov.ua/laws/ show/994 154/sp:max100 (In Ukrainian).

The Law of Ukraine, 2005.Konventsiia pro dostup do informatsii, uchast hromadskosti $\mathrm{v}$ protsesi pryiniattia rishen ta dostup do pravosuddia $\mathrm{z}$ pytan, shcho stosuiutsia dovkillia (Orkhuska konventsiia) [UNECE Convention on Access to Information, Public Participation in Decision-making and Access to Justice in Environmental Matters (Aarhus Convention)] Retrieved from http://zakon.rada.gov.ua/laws/show/994_015/sp:max100 (In Ukrainian).

The Law of Ukraine, 2007.Protokol pro zberezhennia bioriznomanittia ta landshaftiv Chornoho moria do Konventsii pro zakhyst Chornoho moria vid zabrudnennia [Protocol on preservation of biodiversity and landscapes of the Black Sea in the Convention on Protection of the Black Sea against Pollution] Retrieved fromhttp://zakon. rada.gov.ua/laws/show/998_175/sp:max100 (In Ukrainian).

The Law of Ukraine, 2010.Uhoda pro spivrobitnytstvo $\mathrm{v}$ haluzi okhorony navkolyshnoho pryrodnoho seredovyshcha mizh Ministerstvom okhorony navkolyshnoho pryrodnoho seredovyshcha Ukrainy ta Ministerstvom z pytan navkolyshnoho seredovyshcha ta prostorovoho planuvannia Respubliky Makedoniia [Agreement on cooperation in the field of environmental protection between the Ministry of Environmental Protection of Ukraine and the Ministry of Environmental Questions and Territorial Planning of the Republic of Macedonia] Retrieved from http://zakon. rada.gov.ua/laws/show/807 022/sp:max100 (In Ukrainian).

The Law of Ukraine, 2017. Uhoda mizh Ministerstvom ekolohii ta pryrodnykh resursiv Ukrainy ta Ministerstvom okhorony navkolyshnoho seredovyshcha ta rehionalnoho rozvytku Latviiskoi Respubliky pro spivrobitnytstvo v haluzi okhorony navkolyshnoho pryrodnoho seredovyshcha [Agreement between the Ministry of Ecology and Natural Resources of Ukraine and Ministry of Environmental Protection and Regional Development of the Republic of Latvia on cooperation in protection of the surrounding natural environment] Retrieved from http://zakon.rada.gov.ua/ laws/show/428_002-17 (In Ukrainian).

The Law of Ukraine, 2017.Dohovir mizh Kabinetom Ministriv Ukrainy ta Uriadom Respubliky Moldova pro spivrobitnytstvo u sferi okhorony i staloho rozvytku baseinu richky Dnister [The contract between the cabinet of Ukraine and the government of the Republic of Moldova on cooperation in the sphere of protection and sustainable development of Dniester river basin] Retrieved fromhttp:// zakon.rada.gov.ua/laws/show/498_165-12/ sp:max100 (In Ukrainian).

Tofig Rashidov, Talat Kangarli, Ilkin Kangarli, 2018. The prospects of Geoparks creation in Azerbaijan. Conference: 8th International Conference on UNESCO Global GeoparksAt: Madonna di Campiglio, Italy.

UNESCO, 2015. Statutes of the International Geoscience and Geoparks Programme (IGGP). Retrieved from https://unesdoc.unesco.org/ark:/48223/ pf0000234539

UNIAN, 2018. Mizhnarodna ekolohichna orhanizatsiia vidkryie svii ofis v Ukraini[The international ecological organization will open the office in Ukraine] Retrieved from https:/www.unian.ua/ ecology/2348635-mijnarodna-ekologichna-organizatsiya-vidkrie-sviy-ofis-v-ukrajini.html (In Ukrainian).

Yaholnyk, O.V., Manyuk, V.V., 2015. Legal aspects of creating Geoparks in Ukraine. Dniprop.Univer.bulletin, Geology, Geography, 25(2), 136-145. doi: $10.15421 / 111729$

Zinko, Yu.V., Shevchuk, O.M., 2012. Organizacijnoterytorial'ni zasady stvorennja geoparku "Dnistrovs'kyj kan'jon" [Organizational and territorial principles of creation of the "Dniestr Canyon" geopark.] Tourist resources as factor of development of the territory: Materials of the AllUkrainian Scientific and Practical Conference, seminar. Ternopil: Publishing house of Ternopil Volodymyr Hnatiuk National Pedagogical University, 23-30. (In Ukrainian).

Zinko, Yu.V., Shevchuk O.M., 2011. Proektovani heoparky Zakhidnoi Ukrainy [Projected geopark in Western Ukraine] Physical geography and geomorphology. K.: VHL "Obrii”, 3(64), 41-55. (In Ukrainian). 